\title{
$\mathrm{MgB}_{2}$ 線材を用いた液体水素移送ポンプシステムの開発 ${ }^{* 1}$
}

柁川 - 弘 ${ }^{* 2, \dagger}$, 久家 広嗣 ${ }^{* 3}$, 井上 拓郎 ${ }^{* 3}$, 渡辺 和樹 ${ }^{* 3}$, 内田 侑史 ${ }^{* 3}$,
中村 武恒 ${ }^{* 4}$, 小林 弘明 ${ }^{* 5}$, 本鄉 素行 ${ }^{* 5}$, 小島 孝之 ${ }^{* 5}$, 田口 秀之 ${ }^{* 5}$,
成尾 芳博 ${ }^{* 5}$, 和久田 毅*6, 田中 和英 ${ }^{* 6}$

\section{Development of a Liquid Hydrogen Transfer Pump System with $\mathrm{MgB}_{2}$ Wires ${ }^{* 1}$}

\author{
Kazuhiro KAJIKAWA ${ }^{*, \dagger}$, Hirotsugu KUGA ${ }^{* 3}$, Takuro INOUE $^{* 3}$, Kazuki WATANABE $^{* 3}$, Yushi UCHIDA ${ }^{* 3}$, \\ Taketsune NAKAMURA ${ }^{* 4}$, Hiroaki KOBAYASHI ${ }^{* 5}$, Motoyuki HONGO ${ }^{* 5}$, Takayuki KOJIMA ${ }^{* 5}$, \\ Hideyuki TAGUCHI ${ }^{*}$, Yoshihiro NARUO ${ }^{* 5}$, Tsuyoshi WAKUDA ${ }^{* 6}$ and Kazuhide TANAKA ${ }^{* 6}$
}

\begin{abstract}
Synopsis: An electric pump composed of an $\mathrm{MgB}_{2}$ motor is combined with superconducting level sensors using thin CuNisheathed $\mathrm{MgB}_{2}$ wires to transfer liquid hydrogen. An impeller is attached to the lower end of a rotating shaft on the $\mathrm{MgB}_{2} \mathrm{motor}$ and covered with an outer casing to form a centrifugal pump. Then, the $\mathrm{MgB}_{2}$ motor and impeller are placed vertically inside a cryostat with an infill of liquid hydrogen. A glass Dewar vessel is prepared to receive the liquid hydrogen transferred from the cryostat containing the $\mathrm{MgB}_{2}$ motor. The $\mathrm{MgB}_{2}$ sensors are used not only to detect the level of liquid hydrogen but also to control the electric pump on the basis of their pre-estimated calibration curves. By using the assembled pump system, the liquid hydrogen is successfully transferred from the cryostat to the glass Dewar vessel via a transfer tube. (Translation of the article originally published in Cryogenics 52 (2012) 615-619)
\end{abstract}

Keywords: centrifugal pump, liquid hydrogen, magnesium diboride, superconducting level sensor, superconducting motor

(Some figures in this article may appear in colour only in the electronic version.)

\section{1. はじめに}

昨今のエネルギー問題や環境問題を改善するための先進 技術の 1 つとして、水素エネルギー社会の可能性が検討さ

\footnotetext{
Received November 5, 2012

*1 原著論文は Cryogenics 52 (2012) 615-619 に掲載

*2 九州大学 超伝導システム科学研究センター

干819-0395 福岡県福岡市西区元岡 744

Research Institute of Superconductor Science and Systems, Kyushu University, 744 Motooka, Nishi-ku, Fukuoka 819-0395, Japan

*3 九州大学大学院 システム情報科学府

干819-0395 福岡県福岡市西区元岡 744

Graduate School of Information Science and Electrical

Engineering, Kyushu University, 744 Motooka, Nishi-ku, Fukuoka 819-0395, Japan

${ }^{* 4}$ 京都大学大学院 工学研究科

干615-8510 京都府京都市西京区京都大学桂 1

Kyoto University, Kyoto Daigaku Katsura 1, Nishikyo-ku, Kyoto 615-8510, Japan

*5 宇宙航空研究開発機構 研究開発本部

干182-8522 東京都調布市深大寺東町 7-44-1

Japan Aerospace Exploration Agency, 7-44-1 Jindaiji

Higashi-machi, Chofu, Tokyo 182-8522, Japan

*6 (株) 日立製作所 日立研究所

干319-1292 茨城県日立市大みか町 7-1-1

Hitachi Research Laboratory, Hitachi, Ltd., 7-1-1 Omika-cho,

Hitachi, Ibaraki 319-1292, Japan

† E-mail: kajikawa@sc.kyushu-u.ac.jp
}

れている ${ }^{1,2)}$ 。燃料電池等を使って水素を酸化することに よりエネルギーを持続的に得るためには、水素を安全かつ 安定的に製造、輸送、貯蔵、移送するための社会システム を構築する必要がある。その際、圧縮ガスとしてだけでは なく、液化ガスとして水素を利用することも特に大量輸 送・貯蔵の段階で必須となる。何故なら、圧縮水素ガスに 比べて、大気圧下にある液体水素の方が密度は大きいため である ${ }^{3)}$ 。一方、2001 年に発見された新しい金属系超電 導体である二ホウ化マグネシウム $\left(\mathrm{MgB}_{2}\right)$ は $39 \mathrm{~K}$ の臨界 温度を有するため ${ }^{4)}$ 、大気圧下における液体水素の沸点に 近い $20 \mathrm{~K}$ において、電気抵抗ゼロの超電導状態を維持で きる。そこで、 $\mathrm{MgB}_{2}$ 線材を用いた液体水素温度で動作す る超電導機器の実現が期待されている ${ }^{5-11)}$ 。

これまでに、液体水素を循環もしくは移送するための電 気式ポンプを駆動する全超電導モータが提案されている9)。 モータのかご型回転子巻線を $\mathrm{MgB}_{2}$ 線材で構成することに より、同期回転の実現に伴い極低温環境下で発生する損失 を大幅に低減可能となり、同期トルクや出力の向上も見込 まれる ${ }^{12)}$ 。また、モータの固定子巻線を $\mathrm{MgB}_{2}$ 線材で超電 導化することにより、液体水素温度に冷却した銅線に比べ て 1 次巻線損失を大幅に低減可能となる ${ }^{13)}$ 。他方で、 
$\mathrm{CuNi}$ シース $\mathrm{MgB}_{2}$ 線材を用いた超電導式液面計がこれま でに試作され、液体水素中で試験された ${ }^{8)}$ 。その結果、極 低温環境下での発熱量を抑制して液体水素用 $\mathrm{MgB}_{2}$ 液面計 を実現するためには、細線化と臨界温度の低減が有効なこ とがわかった。さらに、ヒータ入力不要な超電導式液面計 を実現するために、CuNi シース $\mathrm{MgB}_{2}$ 線材における常電 導部自動生成現象の物理的機構を実験的に解明した ${ }^{15)}$ 。

本論文では、液体水素を移送するために開発した超電導 ポンプシステムについて述べる。本ポンプシステムの主要 部は、 $\mathrm{MgB}_{2}$ 液面計と $\mathrm{MgB}_{2}$ モータで構成される。 $\mathrm{MgB}_{2}$ 液 面計は、容器内に充填した液体水素の液位の検出だけでは なく、 $\mathrm{MgB}_{2}$ モータの回転制御にも利用した。構築したポ ンプシステムを用いて、液体水素の移送試験を実施した。

\section{2. 超電導式液面計の較正}

容器内に充填した液体水素の液位を検出するために、線 径 $0.0925 \mathrm{~mm}$ と $0.155 \mathrm{~mm}$ をもつ 2 種類の $\mathrm{CuNi}$ シース $\mathrm{MgB}_{2}$ 線材を使用した。両線材の当初の長さは約 $300 \mathrm{~mm}$ である。 $0.0925 \mathrm{~mm}$ 径線材の臨界温度は $30 \mathrm{~K} 、 0.155 \mathrm{~mm}$ 径線材は $33 \mathrm{~K}$ である。これらの線材を用いて、2 本の超 電導式液面計を製作した。各 $\mathrm{MgB}_{2}$ 線材の両端に銅線を事 前に半田付けし、中空のベークライト管の中心軸上に設置 した。銅線は、 $\mathrm{MgB}_{2}$ 線材を直線状に保つとともに、電極 への取り付けを容易にするために使用した。液面計製作後 の有効長は、 $0.0925 \mathrm{~mm}$ 径線材が $260 \mathrm{~mm} 、 0.155 \mathrm{~mm}$ 径線 材が $280 \mathrm{~mm}$ である。CuNi シース $\mathrm{MgB}_{2}$ 線材は、電流通 電に伴い常電導部が自動的に生成するため ${ }^{15)}$ 、電極上部 付近にヒータを取り付けていない。各 $\mathrm{MgB}_{2}$ 線材の感応部 下端のすぐ横に PtCo 温度計を取り付け、この位置に液面 が到達した瞬間の $\mathrm{MgB}_{2}$ 液面計の出力も測定した。

容器内に繰り返し液体水素を充填した際における、製作 した $\mathrm{MgB}_{2}$ 液面計の出力電圧の実験結果を、白印で Fig. 1 に示す。Fig. 1(a), (b)はそれぞれ、0.0925 mm 径と 0.155 $\mathrm{mm}$ 径の $\mathrm{MgB}_{2}$ 液面計の実験結果である。液体水素の液位 は別に、市販の静電容量式液面計を用いて評価したが、そ の下端は $\mathrm{MgB}_{2}$ 液面計よりも数十 $\mathrm{mm}$ 高く、全ての範囲を カバーしていない。実験を何度か繰り返して、0.0925 mm 径と $0.155 \mathrm{~mm}$ 径の $\mathrm{MgB}_{2}$ 液面計における最適電流值をそ れぞれ、150 mA および $300 \mathrm{~mA}$ と決定した。Fig. 1より、 $\mathrm{MgB}_{2}$ 液面計の出力の再現性が非常に良好なことがわかる。 Fig. 1 における実線は、製作した $\mathrm{MgB}_{2}$ 液面計の較正曲線 を表している。また、黒印は、PtCo 温度計が液位を検出 した瞬間における $\mathrm{MgB}_{2}$ 液面計の出力電圧を示している。 各々の $\mathrm{MgB}_{2}$ 液面計に対する静電容量式液面計に基づく較 正曲線を外挿すると、PtCo 温度計に基づいた出力電圧と 良く一致することがわかる。
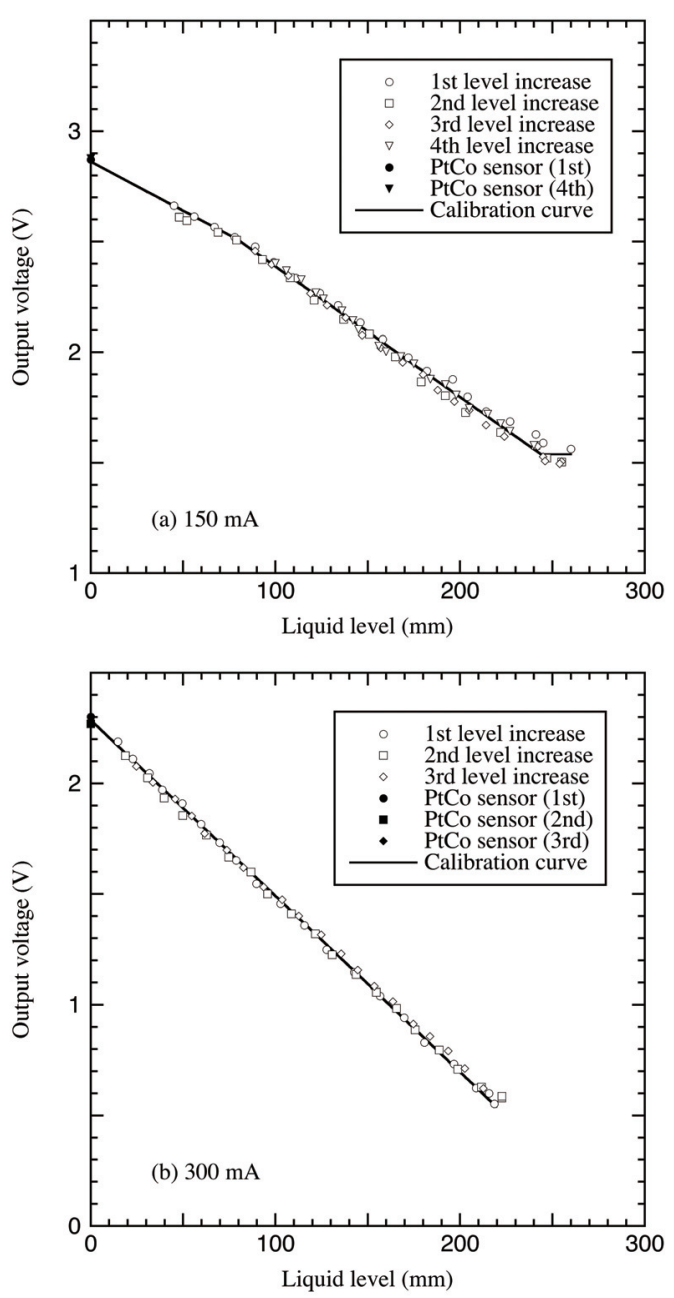

Fig. 1 Dependence of output voltages from liquid hydrogen level sensors with $\mathrm{MgB}_{2}$ wires of diameter (a) $0.0925 \mathrm{~mm}$ and (b) $0.155 \mathrm{~mm}$. The calibration curves are drawn as solid lines.

\section{3. 超電導モータの回転試験}

高温超電導誘導／同期モータ 16-18)を製作するために、 市販誘導機の回転子巻線を $\mathrm{MgB}_{2}$ かご型巻線で置き換えた。 回転子巻線に使用した $\mathrm{MgB}_{2}$ 線材は、外側の銅シースとそ のすぐ内側のニオブシース内に $\mathrm{MgB}_{2}$ 単芯コアをもつ 3 層 構造単芯線である。この $\mathrm{MgB}_{2}$ 線材を無酸素銅製の治具内 に半田で固定し、ローターバーとエンドリングを製作した。 $\mathrm{MgB}_{2}$ 線材の臨界電流は、 $20 \mathrm{~K}$ の自己磁界中で $336 \mathrm{~A}$ であ る。本 $\mathrm{MgB}_{2}$ 回転子巻線は、文献 ${ }^{12)}$ で詳述している。一方、 固定子については、市販誘導機の銅線と鉄心で構成された ものを使用した。この市販誘導機の諸元は、容量 $1.5 \mathrm{~kW}$ 、 入力電圧 $200 \mathrm{~V}$ 、周波数 $60 \mathrm{~Hz}$ である。また、 3 相 4 極の ため、同期回転速度は $1800 \mathrm{rpm}$ である。

液体水素中に浸漬した $\mathrm{MgB}_{2}$ モータに対する無負荷試験 の結果を、Fig. 2 に示す。試験手順として、まず始めに入 力電圧を $0 \mathrm{~V}$ から $200 \mathrm{~V}$ まで一定速度で増加させ、しばら 


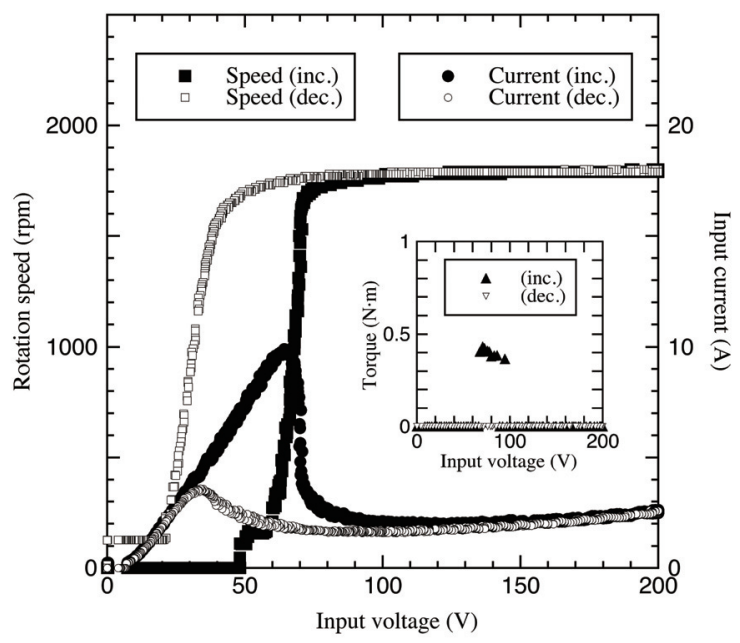

Fig. 2 Experimental results of no-load test of $\mathrm{MgB}_{2}$ motor in liquid hydrogen. The frequency is fixed at $60 \mathrm{~Hz}$. The inset shows the torque for input voltage.

く保持した後、200 V から $0 \mathrm{~V}$ まで入力電圧を減少させた。 周波数は $60 \mathrm{~Hz}$ である。Fig. 2 からわかるように、当初、 $\mathrm{MgB}_{2}$ モータは全く回転せず、入力電流が単調に増加した。 その後、約 $50 \mathrm{~V}$ の入力電圧で $\mathrm{MgB}_{2}$ モータはゆっくりと 回転し始めた。さらに、入力電圧約 $70 \mathrm{~V}$ において、モー 夕の回転速度が同期速度 $1800 \mathrm{rpm}$ に向けて急上昇し、入 力電流も急激に減少した。固定子巻線の 1 相当たりのター ン数は 26.7 なので、減少直前の入力電流の実効值約 $10 \mathrm{~A}$ は、約 $270 \mathrm{~A}$ の二次電流に相当する。これは、回転子巻線 に使用した $\mathrm{MgB}_{2}$ 線材 1 本の臨界電流にほぼ近い值となっ ている。また、Fig. 2 の挿入図からわかるように、回転数 が急上昇する際にのみ約 $0.4 \mathrm{~N} \cdot \mathrm{m}$ のトルクを観測した。さ らに入力電圧を $200 \mathrm{~V}$ まで増加させると、 $\mathrm{MgB}_{2}$ モー夕は ほぼ一定の $1800 \mathrm{rpm}$ で回転し続け、入力電流も再びわず かに上昇した。入力電圧の減少時についても、 $\mathrm{MgB}_{2}$ モー 夕は $1800 \mathrm{rpm}$ の同期回転速度を維持し、数十 V から徐々 にゼロとなった。モータ停止直前の約 $100 \mathrm{rpm}$ の回転速度 は、本研究で使用したタコメータからの見かけの出力であ り、実際の回転速度はゼロである。

\section{4. ポンプシステムを用いた液体水素移送}

\section{1 実験装置の概要}

前記の $\mathrm{MgB}_{2}$ 液面計と $\mathrm{MgB}_{2}$ モー夕を組み合わせた液体 水素移送を実演するために、Fig. 3 に示すようなポンプシ ステムを構築した。 $\mathrm{MgB}_{2}$ モータの下方の回転軸にアルミ 製のインペラ (羽根車) を取り付け、その周囲をケーシン グすることにより遠心ポンプを形成した。インペラの外径、 高さ、ブレード数はそれぞれ、110 mm、6.5 mm、6 枚で ある。外部ケーシングには内径 $20 \mathrm{~mm}$ の噴き出しロが取 り付けてあり、回転速度 $1800 \mathrm{rpm}$ における液体へリウム に対する流量と揚程の設計值はそれぞれ、毎分 120 リット

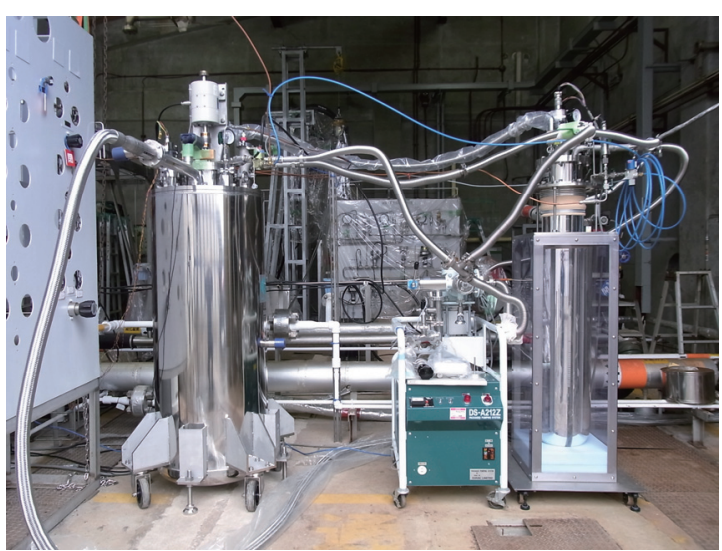

(a)

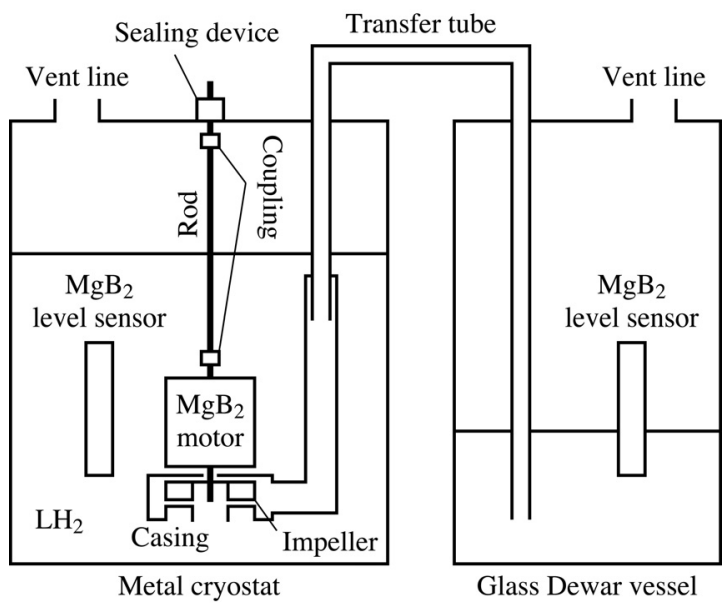

(b)

Fig. 3 (a) Photograph of pump system for demonstration of liquid hydrogen transfer and (b) schematic diagram of pump system with $\mathrm{MgB}_{2}$ motor and $\mathrm{MgB}_{2}$ level sensors.

ルおよび $6 \mathrm{~m}$ である。ただし、 $\mathrm{MgB}_{2}$ モータの回転軸と ケーシングの間にはミリメートル未満のギャップがあり、 インペラにより押し出された冷媒はこのギャップを通して 外部に容易に漏れ出すため、期待される流量は設計值より もずっと小さくなることを付記する。インペラ付きの $\mathrm{MgB}_{2}$ モータを金属（ステンレス）製のクライオスタット 内部に鉛直に配置し、液体水素を充填した。市販されてい る室温用の回転軸付き磁性流体シールを金属製クライオス タットのトップフランジに設置し、 $\mathrm{MgB}_{2}$ モータの回転数 とトルクを室温部で計測した。磁性流体シールと $\mathrm{MgB}_{2}$ モータの回転軸同士を、ステンレス製の延長棒とカップリ ング 2 個を用いて連結した。0.155 mm 径の $\mathrm{MgB}_{2}$ 液面計 を金属製クライオスタット内に鉛直に配置し、その内部の 液体水素の液位を計測した。また、 $\mathrm{MgB}_{2}$ モータを設置し た金属製クライオスタットから移送される液体水素を受け 入れるために、別容器であるガラスデュワーも用意した。 このガラスデュワー内に、もう 1 本の $\mathrm{MgB}_{2}$ 液面計 (0.0925 mm 径) を鉛直に配置し、その内部の液体水素の 液位を計測した。ガラスデュワー内面の銀ペースト間の狭 
いスリットを通して、内部の液体水素の状態を映像として 記録するために、ネットワークビデオカメラも準備した。 金属製クライオスタットとガラスデュワーを、有効内径 $10 \mathrm{~mm}$ のトランスファーチューブを介して接続した。つ まり、最終的な流量の設計值は、内径 $20 \mathrm{~mm}$ の噴き出し 口に対する有効断面積の減少分を考慮すると、4 分の 1 に 小さくなることが想定される。金属製クライオスタットと ガラスデュワーからの蒸発ガスは、直接配管した常圧の心゙ ントラインを通して大気中に放出されるため、両容器内は 常にほぼ大気圧に等しかった。金属製クライオスタットと ガラスデュワーの内径はそれぞれ、400 mm および 153 $\mathrm{mm}$ である。

液体水素の自動送液試験を実施するために、 $\mathrm{MgB}_{2}$ 液面 計からの出力信号を基に $\mathrm{MgB}_{2}$ モータの回転を制御する LabVIEW $^{\circledR}$ プログラムを自作した。試験開始に先立って事 前に設定するモータ制御シーケンスの一例を、Fig. 4 に示 す。Fig. 4 の縦軸は、モータの入力周波数を表している。 一方、横軸は、事前に決定した液位の目標值とガラスデュ ワー内に設置した $0.0925 \mathrm{~mm}$ 径の $\mathrm{MgB}_{2}$ 液面計で観測され る実際の液位との差である。Fig. 4 は、目標值と実際の液 位の差が液面計の有効長 $260 \mathrm{~mm}$ の $20 \%$ よりも小さいとき、 $\mathrm{MgB}_{2}$ モータの入力周波数を $30 \mathrm{~Hz}$ に設定することを意味 する。一方、差が $20 \%$ よりも大きいときは、入力周波数 を $40 \mathrm{~Hz}$ に設定する。ただし、液位が低く、差が 100\%よ りも大きいときは、金属製クライオスタット内の液体水素 残量がモータの冷却に十分な限り、 $\mathrm{MgB}_{2}$ モータへの入力 周波数を $40 \mathrm{~Hz}$ とする。また、実際の液位が目標值よりも 高く、差がゼロよりも小さな場合は、 $\mathrm{MgB}_{2}$ モータに指令 を出さない。 $\mathrm{MgB}_{2}$ モータは、パルス幅変調（PWM）イン バータを $V / f$ 制御して動作させたが、電圧 $V$ と周波数 $f$ の

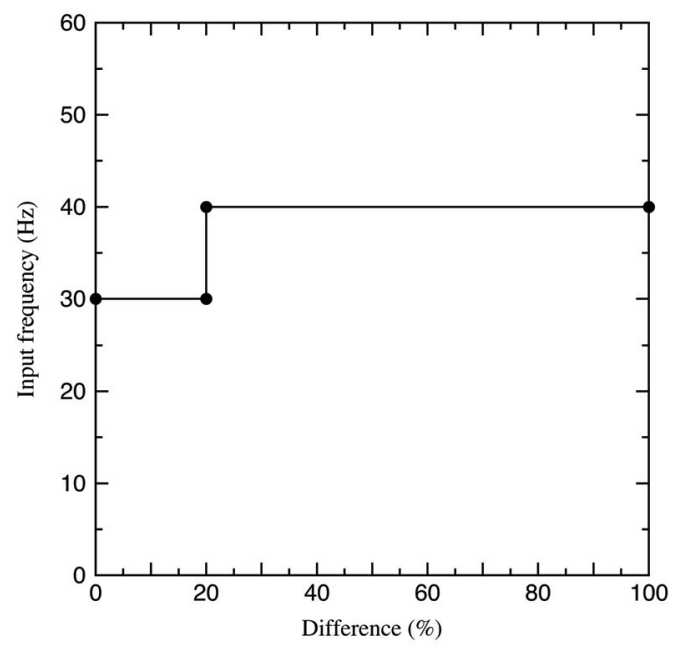

Fig. 4 Example of sequence of motor control for automatic transfer of liquid hydrogen based on difference between predetermined target value and output from level sensor located in glass Dewar vessel.
比を $200 \mathrm{~V} / 60 \mathrm{~Hz}$ に設定した。つまり、PWM インバータ の出力周波数を $30 \mathrm{~Hz}$ （もしくは $40 \mathrm{~Hz}$ ）に設定すると、 出力電圧が $100 \mathrm{~V}$ （もしくは $133 \mathrm{~V}$ ) となる。Fig. 4 の黒 丸は自作プログラムへの入力值を表しており、その隣接す る全ての入力值を補間して各々の実線を生成するため、必 要であれば、Fig. 4 とは異なる任意のモータ制御シーケン スを事前に設定可能である。

\section{2 実験結果}

$\mathrm{MgB}_{2}$ モータの異なる回転速度に対する液体水素の流量 の実験結果を、Fig. 5 に示す。Fig. 5 には、延長棒を取り 付けた場合と取り外した場合の結果を併記しているが、取 り外した場合の回転速度は直接観測できないため、入力周 波数をそのまま回転速度に換算した。Fig. 5 より、回転速 度が $750 \mathrm{rpm}$ 以下のとき、液体水素を全く移送できないこ とがわかる。一方、回転速度が $900 \mathrm{rpm}$ 以上になると、回 転速度とともに流量が増加する。その結果、回転速度 $1800 \mathrm{rpm}$ において、毎分約 6 リットルの流量を得ること ができた。ただし、延長棒を取り付けた場合と取り外した 場合で多少の相違が見られる。流量は幾つかの条件、例え ば、金属製クライオスタット内の微小な圧力変化や液体水 素の残量等に敏感なようであり、有意の差はないといえる。 特に、金属製クライオスタット内の液体水素の残量につい ては、準備した $\mathrm{MgB}_{2}$ 液面計 $(0.155 \mathrm{~mm}$ 径) の有効長が 短く、今回の試験中はほとんどの場合に液体水素中に浸漬 していたため、実験結果に与える影響は評価できなかった。 自作プログラムで事前に設定するモータ制御シーケンス のパターンを幾つか変更して、液体水素の自動送液試験を 実施した。Fig. 6 は、Fig. 4 に示すモータ制御シーケンス に基づく実験結果の一例である。Fig. 6(a)は、ガラスデュ ワー内に設置した $0.0925 \mathrm{~mm}$ 径の $\mathrm{MgB}_{2}$ 液面計により測定

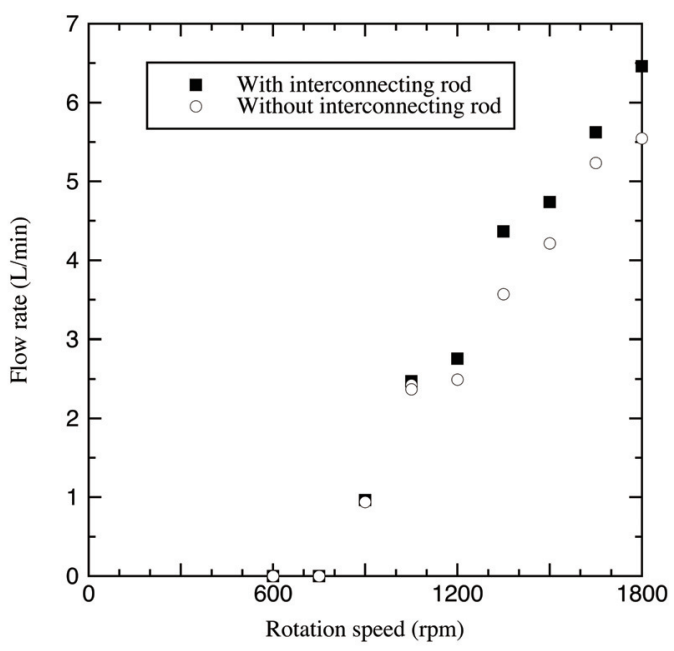

Fig. 5 Experimental flow rates of liquid hydrogen for fixed rotation speeds. Flow rates are observed for the cases with and without the rod to connect the magnetic fluid sealing device with the upper end of rotating shaft of the motor. 

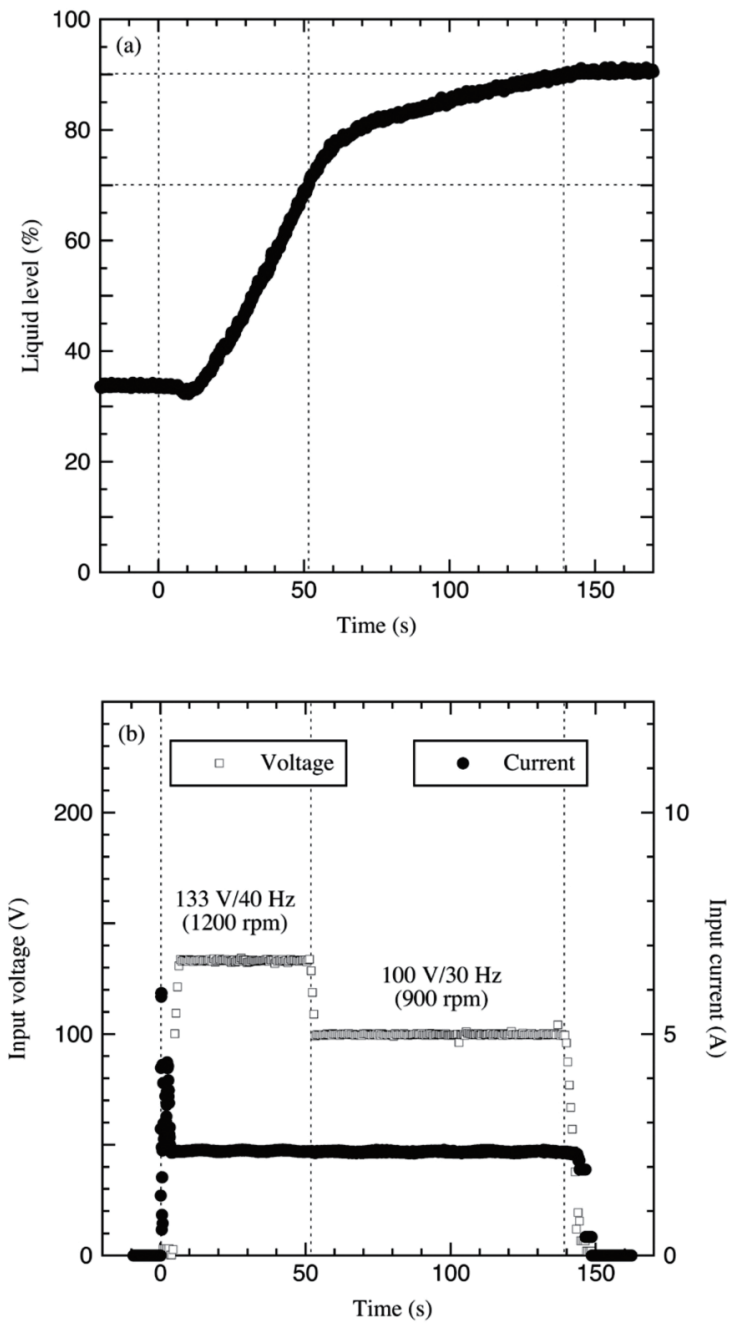

Fig. 6 Examples of automatic transfer of liquid hydrogen. (a) represents the time evolution of the liquid level in the glass Dewar vessel measured by the $\mathrm{MgB}_{2}$ level sensor with 0.0925 $\mathrm{mm}$ wire, whereas (b) shows the temporal dependence of input voltage and current of the $\mathrm{MgB}_{2}$ motor inside the metal cryostat. The vertical dashed lines represent the times when the motor's rotation speeds begin to vary.

した液位の時間変化を表している。一方、Fig. 6(b)は、金 属製クライオスタット内に設置した $\mathrm{MgB}_{2}$ モータの入力電 圧と入力電流の時間変化である。Fig. 6 からわかるように、 ガラスデュワー内の液体水素の液位は、当初約 $34 \%$ で あった。90\%の液位を目標值として指定すると、 $\mathrm{MgB}_{2}$ モータは時刻 $t=0$ に回転速度 $1200 \mathrm{rpm}$ で回転し始めた。 その後、トランスファーチューブ内の温かい水素ガスが流 入することにより、ガラスデュワー内の液位はわずかに下 降するが、トランスファーチューブ内が冷却されると、ほ ぼ一定速度で液位は上昇し始めた。ガラスデュワー内の液

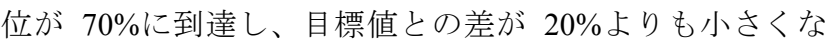
ると、シーケンスに従って $\mathrm{MgB}_{2}$ モータの回転数は自動的
に $1200 \mathrm{rpm}$ から $900 \mathrm{rpm}$ 一変化した。その結果、流量は 急激に低下した。最終的にガラスデュワー内の液位が目標 值である 90\%に到達すると、 $\mathrm{MgB}_{2}$ モータの回転は自動的 に停止し、液位は 90\%付近で一定となった。このように、 自作プログラムにより $\mathrm{MgB}_{2}$ 液面計の出力に基づいて $\mathrm{MgB}_{2}$ モータを回転制御できたが、ポンプシステムの実用 化に際しては、より複雑なモータ制御シーケンスが必要と なる。 $\mathrm{MgB}_{2}$ モータの回転中における入力電流は、始動時 以外は $2.35 \mathrm{~A}$ でほぼ一定だった。

\section{5. まとめ}

$\mathrm{MgB}_{2}$ モータと $\mathrm{MgB}_{2}$ 液面計を組み合わせた、液体水素 移送ポンプシステムを構築した。 $\mathrm{MgB}_{2}$ モータの回転軸の アルミ製のインペラを取り付けてケーシングすることによ り、遠心ポンプを形成した。 $\mathrm{MgB}_{2}$ 液面計は、容器内にあ る液体水素の液位を検出するだけではなく、 $\mathrm{MgB}_{2}$ モータ の回転制御にも利用した。構築したポンプシステムを用い て、充填容器から別容器への液体水素の移送に成功した。

本研究は、新エネルギー・産業技術総合開発機構 (NEDO) の平成 20 年度産業技術研究助成事業（課題番 号：08B38006a）の一環として実施したものである。

\section{参 考 文 献}

1) H. Hirabayashi: "Liquid hydrogen and applied superconductivity -For advanced utilization in the community-," TEION KOGAKU 40 (2005) 276-283 (in Japanese)

平林洋美 :「液体水素と超伝導応用一広く社会に普及させる ために一」，低温工学 40 (2005) 276-283

2) P. Mikheenko: "Superconductivity for hydrogen economy," J. Phys. Conf. Ser. 286 (2011) 012014

3) R.D. McCarty: "Hydrogen technology survey - Thermophysical properties," NASA Special Publication SP-3089 (1975)

4) J. Nagamatsu, N. Nakagawa, T. Muranaka, Y. Zenitani and J. Akimitsu: "Superconductivity at $39 \mathrm{~K}$ in magnesium diboride," Nature 410 (2001) 63-64

5) P.M. Grant: "The SuperCable: Dual delivery of chemical and electric power," IEEE Trans. Appl. Supercond. 15 (2005) 18101813

6) Ch. Haberstroh and G. Zick: "A superconductive $\mathrm{MgB}_{2}$ level sensor for liquid hydrogen,” Adv. Cryo. Eng. 51 (2006) 679-684

7) M. Takeda, Y. Matsuno, I. Kodama and H. Kumakura: "Characteristics of $\mathrm{MgB}_{2}$ sensor for detecting level of liquid hydrogen,” Adv. Cryo. Eng. 53 (2008) 933-939

8) K. Kajikawa, K. Tomachi, N. Maema, M. Matsuo, S. Sato, K. Funaki, H. Kumakura, K. Tanaka, M. Okada, K. Nakamichi, Y. Kihara, T. Kamiya and I. Aoki: "Fundamental investigation of a superconducting level sensor for liquid hydrogen with $\mathrm{MgB}_{2}$ wire," J. Phys. Conf. Ser. 97 (2008) 012140

9) K. Kajikawa and T. Nakamura: "Proposal of a fully superconducting motor for liquid hydrogen pump with $\mathrm{MgB}_{2}$ wire," IEEE Trans. Appl. Supercond. 19 (2009) 1669-1673 
10) Y. Shirai, H. Tatsumoto, M. Shiotsu, K. Hata, H. Kobayashi, Y. Naruo, Y. Inatani and K. Kinoshita: "Forced flow boiling heat transfer of liquid hydrogen for superconductor cooling," Cryogenics 51 (2011) 295-299

11) T. Hamajima, H. Amata, T. Iwasaki, N. Atomura, M. Tsuda, D. Miyagi, T. Shintomi, Y. Makida, T. Takao, K. Munakata and M. Kajiwara: "Application of SMES and fuel cell system combined with liquid hydrogen vehicle station to renewable energy control," IEEE Trans. Appl. Supercond. 22 (2012) 5701704

12) T. Nakamura, Y. Yamada, H. Nishio, K. Kajikawa, M. Sugano, N. Amemiya, T. Wakuda, M. Takahashi and M. Okada: "Development and fundamental study on a superconducting induction/synchronous motor incorporated with $\mathrm{MgB}_{2}$ cage windings," Supercond. Sci. Technol. 25 (2012) 014004

13) K. Kajikawa, R. Osaka, T. Nakamura, M. Sugano and T. Wakuda: "AC loss evaluation of $\mathrm{MgB}_{2}$ superconducting windings located in a stator core slot with a finite-element method," J. Supercond. Nov. Magn. 24 (2011) 987-991

14) K. Kajikawa, K. Tomachi, K. Tanaka, K. Funaki, T. Kamiya, M. Okada and H. Kumakura: "Numerical simulation of a superconducting level sensor for liquid hydrogen with $\mathrm{MgB}_{2}$ wire," Proc. of ICEC22/ICMC2008 (2009) 425-430

15) A. Jokinen, K. Kajikawa, M. Takahashi and M. Okada: "Automatic development of normal zone in composite $\mathrm{MgB}_{2} / \mathrm{CuNi}$ wires with different diameters," J. Phys. Conf. Ser. 234 (2010) 012021

16) T. Nakamura, H. Miyake, Y. Ogama, G. Morita, I. Muta and T. Hoshino: "Fabrication and characteristics of HTS induction motor by the use of Bi-2223/Ag squirrel-cage rotor," IEEE Trans. Appl. Supercond. 16 (2006) 1469-1472

17) T. Nakamura, Y. Ogama, H. Miyake, K. Nagao and T. Nishimura: "Novel rotating characteristics of a squirrel-cage-type HTS induction/synchronous motor," Supercond. Sci. Technol. 20 (2007) 911-918

18) T. Nakamura, K. Nagao, T. Nishimura, Y. Ogama, M. Kawamoto, T. Okazaki, N. Ayai and H. Oyama: "The direct relationship between output power and current carrying capability of rotor bars in HTS induction/synchronous motor with the use of DI-BSCCO tapes," Supercond. Sci. Technol. 21 (2008) 085006

柁 川 - 弘 1968 年生。1990 年九州大学工学部電子工学 科卒業。1992 年同大学院工学研究科修士課程（電子工学専攻） 修了。現在、九州大学超伝導システム科学研究センター准教授。 主に超伝導線の電磁特性評価や熱的安定性評価、および超伝導技 術の液体水素応用に関する研究開発に従事。低温工学・超電導学 会、電気学会、応用物理学会、IEEE 会員。博士 (工学)。

久 家 広 嗣 1987 年生。2010 年九州大学工学部電気情報 工学科卒業。2012 年同大学院システム情報科学府修士課程（電 気電子工学専攻) 修了。 $\mathrm{MgB}_{2}$ モータおよび液体水素移送ポンプ の研究開発に従事。現在、九州旅客鉄道 (株) 勤務。

井 上 拓 郎 1987 年生。2010 年九州大学工学部電気情報 工学科卒業。2012 年同大学院システム情報科学府修士課程（電 気電子工学専攻) 修了。 $\mathrm{MgB}_{2}$ 液面計の研究開発に従事。現在、 九州電力 (株) 勤務。
渡 辺 和 樹 1988 年生。2011 年九州大学工学部電気情報 工学科卒業。現在、同大学院システム情報科学府修士課程（電気 電子工学専攻) 在学。 $\mathrm{MgB}_{2}$ 液面計の研究開発に従事。低温工 学・超電導学会、電気学会会員。

内 田 侑 史 1989 年生。2012 年九州大学工学部電気情報 工学科卒業。現在、同大学院システム情報科学府修士課程（電気 電子工学専攻) 在学。 $\mathrm{MgB}_{2}$ モータの研究開発に従事。低温工 学・超電導学会、電気学会会員。

中 村 武 恒 1969 年生。1993 年九州大学工学部電子工学 科卒業。1998 年同大学院システム情報科学研究科博士後期課程 （電気電子システム工学専攻）修了。同年京都大学勤務。2005 年同助教授、現在同准教授。主として、車載システム、分散電 源、超電導回転機と同マグネット技術開発に従事。低温工学・超 電導学会、電気学会、応用物理学会、未踏科学技術協会 (超電導 科学技術研究会)。博士 (工学)。

小林弘 明 1972 年生。東京都出身。2001 年東京大学大 学院工学系研究科航空宇宙工学専攻博士課程修了、博士（工 学)。同年宇宙科学研究所に入所、ATREX エンジン研究開発に従 事した後、現在、宇宙航空研究開発機構ジェットエンジン技術研 究センター主任研究員。専門：極超音速推進・極低温燃料技術。

本 郷 素 行 1960 年生。東京都出身。1985 年東海大学工 学部卒業。1986 年東京大学工学部精密機械工学科技官。1990 年 文部省宇宙科学研究所技官を経て、現在、宇宙航空研究開発機構 研究開発本部ジェットエンジン技術研究センター主任研究員。極 超音速推進システムの研究開発に従事。

小島 孝之 1973 年生。神奈川県出身。2002 年東京大学 大学院工学系研究科航空宇宙工学専攻博士課程修了、博士（工 学)。同年宇宙科学研究所 COE 研究員、2003 年航空宇宙技術研 究所入所。現在、宇宙航空研究開発機構航空プログラムグループ 事業推進部主任。

田口秀之 1968 年生。杤木県出身。1993 年東京大学大 学院工学系研究科航空学専攻修士課程修了、2005 年博士（工 学)。三菱重工業(株)を経て、1996 年航空宇宙技術研究所入所。 現在、宇宙航空研究開発機構研究開発本部ジェットエンジン技術 研究センター主幹研究員。

成尾 芳 博 1953 年生。長野県出身。1977 年日本大学大 学院理工学研究科機械工学専攻修士課程修了。同年、東京大学宇 宙航空研究所入所、1981 年宇宙科学研究所助手を経て、現在、 宇宙航空研究開発機構宇宙科学研究所宇宙飛翔工学研究系助教。 液水エンジン及び再使用型宇宙輸送システムの研究開発に従事。

和 久 田 毅 1969 年生。1992 年九州大学工学部電子工学 科卒業。1997 年同大学院システム情報科学研究科博士後期課程 (電気電子システム工学専攻) 修了。現在、(株) 日立製作所日立 研究所に勤務。主に超伝導マグネットの研究開発に従事。低温工 学・超電導学会、電気学会会員。博士 (工学)。

田 中 和 英 1987 年(株) 日立製作所日立研究所に勤務。 主として酸化物系・ $\mathrm{MgB}_{2}$ 超電導線材の開発に従事。2 009 年 3 月 九州大学大学院システム情報科学府博士後期課程（電気電子シス テム工学専攻) 修了。低温工学・超電導学会、応用物理学会会 員。博士 (工学)。 